\title{
PREVALENCE OF DENTAL DECAY AND PERIODONTAL DISEASES AMONG CHILDREN SUFFERING FROM CONGENITAL HEART DISEASES. A LITERATURE REVIEW - PART I
}

\author{
Teodora Nikolova ${ }^{1}$, Radosveta Andreeva ${ }^{1}$, Milena Georgieva ${ }^{1}$, Petar Shivachev ${ }^{2}$
}

${ }^{1}$ Department of Pediatric Dentistry, Faculty of Dental Medicine, Medical University of Varna

${ }^{2}$ Department of Paediatrics, Faculty of Medicine, Medical University of Varna

\begin{abstract}
Congenital heart disease (CHD) is one of the most common congenital anomalies with an incidence of approximately 8-10 cases per 1000 live births. The etiology behind cardiac developmental disturbances is unknown for a majority of cases.

It is known that children with CHD frequently require regular long-term medication, but the knowledge of oral health effects, caused by long-term medication in medically compromised children, is sparse. If left untreated, $\mathrm{CHD}$ is the single greatest cause of death during the neonatal period after full-time pregnancies in the industrialized part of the world.

A number of studies have been carried out on the caries prevalence in children with CHD, but only five of them were controlled studies. According to one of them children with CHD had a higher number of registered periodontal sites with plaque and gingival inflammation than the healthy control group of children, although nearly all examined patients had plaque registered. Children with CHD had higher mean values of $\mathrm{dmft}$ /DMFT indices than healthy children and only a few of them had dental fillings, indicating an unmet need for operative treatment.

Today surgical treatment is successful for the majority of children born with CHD. The median age of children subjected to heart surgery today is below 2 years of age. We need to continuously improve the oral health by providing education and training for both dental and medical health care specialists on oral health problems and their prevention in this new group of patients.
\end{abstract}

Keywords: congenital heart disease (CHD), dental decay, periodontal disease, children, risk factors, medication

Address for correspondence:

Teodora Nikolova

Faculty of Dental Medicine

84, Tsar Osvoboditel Blvd.

9000 Varna

e-mail: tedinikolova1@gmail.com

Received: December 3, 2017

Accepted: December 29, 2017

\section{CONGENITAL HEART DISEASES -}

DEFINITION, ETIOLOGY, CLASSIFICATION AND PREVALENCE

The human heart develops between $8^{\text {th }}$ and $12^{\text {th }}$ gestational week and disturbances in this process may cause an anomaly - a congenital heart disease (CHD). CHD is one of the most common congenital anomalies with an incidence of approximately 8-10 cases per 1000 live births (1-7). Children with complex anomalies represent approximately one third 
Teodora Nikolova, Radosveta Andreeva, Milena Georgieva et al.

of all CHD cases (1-5). The ongoing technical and methodological improvements in surgery have led to the possibility for early surgical interventions and lower morbidity rates among children with CHD (1$3,5,8)$. The majority of children with CHD nowadays are subjected to successful surgery, but for many of them, suffering from complex CHD, surgery is only a palliative treatment $(9,10)$.

The etiology behind CHD stays unknown for the majority of cases, but there are some possible risk factors such as diseases and infections of the mother like rubella, diabetes, HIV and chronic intoxications, that have been reported $(11,6)$. Many CHDs are hereditary but modified by extrinsic factors (7). In most of the cases CHD occurs as an isolated impairment, but it can also be a part of a syndrome or of some genetic malformations such as Down's syndrome, Noonan's syndrome, Turner's syndrome and trisomy 18 . Approximately $40 \%$ of children suffering from Down's syndrome and trisomy 18 have a CHD $(12,13)$.

The most common cardiac developmental disturbances may be classified in three sub-groups as follows: CHD with left-right shunt, CHD with right-left shunt, and obstructive heart diseases (Table 1) $(2,14)$.

Congenital heart anomalies represent $28 \%$ of all congenital anomalies $(3,15)$. The mean incidence is 8 out of $1000(2,3,12)$. A meta-analysis of online specialized database from 2011 reviewed 114 online sources and revealed rising levels of the prevalence of CHD for the period 1930-1995, from 0.6 to 9 out of every 1000 live births $(3,12)$.

A scientific research in Sudan (2007) reveals that the prevalence of CHD among Sudanese children aged 5-15 is 2 out of every1000 live births $(3,16)$.
In 2013, the most common CHDs are represented by atrioventricular septal defect (AVSD), ventricle septal defect (VSD), patent ductus arteriosus (PDA), pulmonary stenosis (PS) and tetralogy of Fallot and comprise up to 83\% all CHDs in Sudan (2).

There is not enough epidemiological data concerning CHDs in Bulgaria. Citing the register of congenital anomalies for the region of Pleven (2011), the prevalence of CHD is found to be 5-6 out of every 1000 live births (2). During an epidemiological research of Pilosof V. et al. (1979), concerning 6 regions of Bulgaria, the prevalence of CHD was measured to be 7.4/1000 $(2,3)$. According to the same sources $12.5 \%$ of all CHD were critical.

\section{Symptoms of CHD}

The main symptoms of CHD are cyanosis and/ or heart failure. In cyanosis, de-oxygenated blood is mixed with oxygenated blood or an increased amount of blood goes to the pulmonary circulation (7). Low saturation in tissues and organs may lead to acidosis, and this may cause an impaired heart function and heart failure $(3,6)$.

Heart failure is either due to an increased blood flow to the pulmonary circulation or due to a deformed ventricle, which fails to keep the pumping function. Blood will fill the lungs, and breathing will be affected. The clinical signs are tachypnea and tachycardia, feeding problems, and inadequate weight gain. The first symptoms of heart failure are often observed during the child's first 3 months of life $(2,3)$.

\section{Common Clinics and Oral Manifestations of Common CHDs}

According to a research from 2016, bicuspid aortic valve (BAV) is the most common $\mathrm{CHD}$. BAV

Table 1. Classification of congenital heart malformations according to Abbott

\section{Classification of congenital heart diseases according to Abbott}
I. CHD with left-right shunt
II. CHD with right-left shunt (Cyanotic vitia)
III. CHD without a shunt (Obstructive heart diseases)
2. Atrial septal defect (ASD)
3. Patent ductus arteriosus (PDA)
4. Atrioventricular septal defect (AVSD)
1. Tetralogy of Fallot (TOF)
2. Transposition of the great arteries (TGA)
1. Aortic stenosis (AS)
2. Coarctation of the aorta (CoA)
3. Pulmonary stenosis (PS)

1. Ventricle septal defect (VSD) 
Prevalence of Dental Decay and Periodontal Diseases Among Children Suffering from Congenital Heart Diseases. ...

is an inherited form of heart disease in which two of the leaflets of the aortic valve fuse during development in the womb resulting in a two-leaflet valve (bicuspid valve) instead of the normal three-leaflet valve (tricuspid) (17-21). BAV is not only due to a defect during embryogenesis (congenital) but is usually a part of more complex genetically induced disturbances of heart's development (inherited) $(19,21)$. The morphogenesis of the heart and its valves takes place in an early stage of the embryotic development $(19,20)$ and BAV presents a disturbance in mesodermal tissue $(19,22)$. BAV may be present as a part of Williams' or Turner's syndrome $(19,21,23)$. The gravity of clinical symptoms may vary from asymptomatic state during the period of lactation and early childhood to grave disturbances in the valve function in elders $(19,21,23,24)$. Typical symptoms after entering puberty are syncopes, angina pectoralis and breathing difficulties $(19,21,24,25)$.

A clinical research presents a case of a patient with BAV, observed from childhood till puberty. The gravity of clinical symptoms of the CHD increased in time, and by the time of puberty the patient already had the three typical symptoms present (syncopes, angina pectoralis and breathing difficulties). The only impairment observed during early childhood was hypodontia of the upper lateral primary incisors. Worsening of the aortic stenosis led to inadequate growth and weight gain (compared to healthy children of the same age) and immature ossification of the wrist bones (the skeletal age -7 was lower than the biological one -9 years of age) (19).

\section{TREATMENT OF CHD}

\section{Surgical Treatment}

The first pediatric cardiac surgery was performed in 1938. The first heart-lung machine was used in 1953, and since 1970 pacemaker and heart transplantations on newborns have been used in pediatric cardiology. During the 1980s, some catheter surgeries for $\mathrm{CHD}$ became possible. The use of prostaglandin on patients with duct-dependent heart anomalies and the development of diagnostic echocardiography changed the prognosis for children with CHD and increased their survival rate. Today, even children born with very complex CHD, may have successful surgery $(2,3,19)$. Nowadays, the mean age for cardiac surgery is below 2 years of age $(2,3,6)$.

\section{Pharmacological Treatment}

If left untreated, CHD is the main reason for death in the neonatal period in the industrialized part of the world $(6,7)$.

Diuretics are the first medication of choice for treatment of heart failure, because they diminish the overall blood volume and thus decrease heart loading. Therapy with angiotensin-converting enzyme inhibitors (ACE-inhibitors) and/or cardiac glycosides may also be indicated for heart failure. ACEinhibitors prevent angiotensin II formation and thus decrease the peripheral resistance both during preload and afterload (26-28). Digitalis preparations lower the heart rate and stimulate the contractility of the heart muscle. Beta-blockers are used for treatment of cardiac arrhythmias and may be prescribed as adjunct therapy for heart failure (30-32). Anti-coagulants such as warfarin, which hinders blood clot formation, and anti-platelet drugs such as acetylsalicylic acid, decrease platelet aggregation. They are used to prevent thrombotic events for diagnosed cardiovascular diseases (26-28).

For CHD with communication between left and right heart present, for pulmonary stenosis or for hypoplastic left heart syndrome, the patency of the ductus is crucial, otherwise the child is going to die. In the late 1970s prostaglandin was found to manage this patency of the arterial canal and thus dramatically improved the results of pediatric cardiac surgery. After prostaglandin infusion, children with CHD can be successfully stabilized and transported to appropriate surgery under better circumstances (28).

Pharmaceutical preparations, used for children with complex CHD, are usually combined. The most commonly used medications in pediatric cardiology are listed in Table 2 (26-28).

Risk Factors for Decay and/or Periodontal Disease Occurrence in Children with CHD

The potential risk factor is a variable related to a higher risk of infection and/or disease. The exposure to the potential risk factor must be present by the time of the resulting disease and this implies the need for prospective studies to prove them as actual risk factors (29). Lowered salivary flow and high numbers of acidogenic oral flora are well known risk factors for decay and/or periodontal disease occur- 
Teodora Nikolova, Radosveta Andreeva, Milena Georgieva et al.

Table 2. Medications, commonly used for treatment of cardiovascular diseases in children.

\begin{tabular}{ll}
\hline Pharmaceutical group & Generics \\
Beta-blockers & $\begin{array}{l}\text { Propranolol } \\
\text { Metoprolol }\end{array}$ \\
Cardiac glycosides & Digoxin \\
ACE inhibitors & Captopril \\
& Enalapril \\
& Furantril \\
Diuretics & $\begin{array}{l}\text { Furosemide } \\
\text { Spironolactone }\end{array}$ \\
Anti-platelet medicine & Acetylsalicylic acid \\
Anti-coagulants & Sintrom \\
\hline \hline
\end{tabular}

rence. The gravity of the risk factors for decay formation varies in time for they are affected by behavioral habits. Poor oral hygiene habits, inadequate diet, long-term medication with sugar- and/or acid-containing preparations, or xerogenic ones, are all proper examples of behavioral habits that lead to higher risk of decay formation (33).

There are a few risk factors linked to children with CHD, which by themselves or in a combination, may lead to a greater possibility of decay formation:

1. inadequate weight gain and hindered growth, usually managed with extra feedings even during night time (30,31);

2. long-term medication with peroral antibiotics, which contain saccharose (30);

3. reduced salivary flow, caused by medical preparations used in pediatric cardiology $(10,30)$;

4. parents are mainly concerned with the cardiac disease and neglect oral health (30).

In addition, a recent study on a group of children with CHD proves that the enamel and dentine of their primary teeth were structurally and chemically different from normal ones, presenting lower values of overall calcium and phosphates levels $(30,32,34)$.

\section{REFERENCES}

1. Peneva M, Tzolova E, Kabakchieva R, Rashkova M. Oral embryology, histology and biology. A Book of Pediatric Dentistry, Sofia; 2007.

2. Shivachev P, Marinov L, Tzonsarova M, Lazarov S, Mitev P. Postoperative mortality and risk factors in patients with critical congenital heart malformations. Pediatrics. 2013; 53(4):21-5.

3. Ali HM, Mustafa M, Nasir EF, Lie SA, Hasabalrasol S, Elshazali OH, et al. Oral-health-related background factors and dental service utilisation among Sudanese children with and without a congenital heart defects. BMC Oral Health. 2016; 16(1):123. doi: 10.1186/s12903-016-0318-5.

4. Busuttil Naudi A, Mooney G, El-Bahannasawy E, Vincent C, Wadhwa E, Robinson D, et al. The dental health and preventative habits of cardiac patients attending the Royal Hospital for Sick Children Glasgow. Eur Arch Paediatr Dent. 2006;7(1):23-30.

5. Hoffman JI, Kaplan S. The incidence of congenital heart disease. J Am Coll Cardiol. 2002;39(12):1890-900.

6. Sunnegardh J. Barnkardiologi - en oversikt. First ed. Lund: Studentlitteratur; 2000.

7. The National Board of Health and Welfare (Socialstyrelsen). Nationella riktlinjer for hjartsjukvard 2008 (In Swedish). Socialstyrelsens publikationer, artikelnummer 2008ᄀ102-7. 2008.

8. Bhat AH, Sahn DJ. Congenital heart disease never goes away, even when it has been 'treated': the adult with congenital heart disease. Curr Opin Pediatr. 2004;16(5):500-7.

9. Reybrouck T, Vangesselen S, Gewillig M. Impaired chronotropic response to exercise in children with repaired cyanotic congenital heart disease. Acta Cardiol. 2009;64(6):723-7. doi: 10.2143/ AC.64.6.2044734

10. Rosen L, Rydberg A, Sjostrom I, Stecksen-Blicks C. Saliva profiles in children using heart failure medication: a pilot study. Eur Arch Paediatr Dent. 2010;11(4):187-91.

11. Burd L, Deal E, Rios R, Adickes E, Wynne J, Klug MG. Congenital heart defects and fetal alcohol spectrum disorders. Congenit Heart Dis. 2007;2(4):250-5. doi: 10.1111/j.1747-0803.2007.00105.x.

12. van der Linde D, Konings EE, Slager MA, Witsenburg M, Helbing WA, Takkenberg JJ, et al. Birth prevalence of congenital heart disease worldwide: a systematic review and meta-analysis. J Am Coll Cardiol. 2011;58(21):2241-7. doi: 10.1016/j. jacc.2011.08.025. 
Prevalence of Dental Decay and Periodontal Diseases Among Children Suffering from Congenital Heart Diseases. ...

13. Wang JJ, Attia J. Study designs in epidemiology and levels of evidence. Am J Ophthalmol. 2010;149(3):367-70. doi: 10.1016/j.ajo.2009.08.001.

14. Richardson P, McKenna W, Bristow M, Maisch B, Mautner B, O'Connell J, et al. Report of the 1995 World Health Organization/International Society and Federation of Cardiology Task Force on the Definition and Classification of cardiomyopathies. Circulation. 1996;93(5):841-2.

15. Dolk H, Loane M, Garne E. European Surveillance of Congenital Anomalies (EUROCAT) Working Group. Congenital heart defects in Europe: prevalence and perinatal mortality, 2000 to 2005. Circulation. 2011;123(8):841-9. doi: 10.1161/ CIRCULATIONAHA.110.958405.

16. Sulafa KM, Karani Z. Diagnosis, management and outcome of heart disease in Sudanese patients. East Afr Med J. 2007;84(9):434-40.

17. Sans-Coma V, Fernández B, Durán AC, Thiene G, Arqué JM, Muñoz-Chápuli R, et al. Fusion of valve cushions as a key factor in the formation of congenital bicuspid aortic valves in Syrian hamsters. Anat Rec. 1996; 244(4):490-8. doi: 10.1002/(SICI)10970185(199604)244:4<490::AID-AR7>3.0.CO;2-Z.

18. Allen HD, Driscoll DJ, Shaddy RE, Feltes TF. Moss and Adams' Heart Disease in Infants, Children, and Adolescents. Philadelphia: Lippincott Williams \& Wilkins; 2008.

19. American Academy of Pediatric Dentistry (AAPD). Guideline on periodicity of examination, preventive dental services, anticipatory guidance/counseling, and oral treatment for infants, children, and adolescents. Pediatr Dent. 2013; 35(5): E148-E156.

20. Fedak PWM, Verma S, David TE, Leask RL, Weisel RD, Butany J. Clinical and pathophysiological implications of a bicuspid aortic valve. Circulation. 2002; 106(8):900-4.

21. Raducanu AM, Feraru IV, Suicu I, Teodorescu E, Andidelescu AC, Ionescu I, et al. Common and unusual dental development abnormalities in a patient with bicuspid aortic valve. Rom J Morphol Embryol. 2016;57(2 Suppl):871-3.

22. Siu SC, Silversides CK. Bicuspid aortic valve disease. J Am Coll Cardiol. 2010; 55(25):2789-800. doi: 10.1016/j.jacc.2009.12.068.

23. Pucéat M. Embryological origin of the endocardium and derived valve progenitor cells: from developmental biology to stem cell-based valve repair.
Biochim Biophys Acta, 2013, 1833(4): 917-22. doi: 10.1016/j.bbamcr.2012.09.013.

24. Satish C, Shaleen C, Girish C, Kamala R. Oral medicine. Jaypee Brothers Medical Publishers; 2007. p. $153-8$.

25. Apetrei E. Valvulopatiile. În: Gherasim L (ed). Medicina internă. Vol. II: Bolile cardiovasculare metabolice. Ed. Medicală, Bucureşti; 2001. p. 321-2.

26. Carabello BA, Crawford MH. Aortic stenosis. In: Crawford $\mathrm{MH}$ (ed). Current diagnosis \& treatment in cardiology. 3rd edition. McGraw-Hill/Appleton \& Lange; 2009. p. 82-7.

27. NIH (2014) National Heart, Lung and Blood Institute, USA. How are congenital heart defects treated? Available at: www.nhlbi.nih.gov/healthy/ health-topics/topics/chd/treatment.html.

28. WebMD (2014) Congenital heart defects medications. The Heart Disease Health Center, USA. Available at: www.WebMD.com/heart-disease/tc/ congenital-heart-defects-medications.

29. Sun RR, Liu M, Lu L, Zheng Y, Zhang P. Congenital heart disease: causes, diagnosis, symptoms, and treatments. Cell Biochem Biophys. 2015;72(3):85760. doi: 10.1007/s12013-015-0551-6.

30. Selwitz RH, Ismail AI, Pitts NB. Dental caries. Lancet. 2007;369(9555):51-9. DOI: 10.1016/ S0140-6736(07)60031-2.

31. Ali HM, Mustafa M, Hasabalrasol S, Elshazali OH, Nasir EF, Ali RW, Berggreen E et al. Presence of plaque, gingivitis and caries in Sudanese children with congenital heart defects. Clin Oral Investig. 2017; 21(4): 1299-307. doi: 10.1007/ s00784-016-1884-2.

32. Stecksen-Blicks C, Rydberg A, Nyman L, Asplund $\mathrm{S}$, Svanberg C. Dental caries experience in children with congenital heart disease: a case-control study. Int J Paediatr Dent. 2004;14(2):94-100.

33. Burt BA. Concepts of risk in dental public health. Community Dent Oral Epidemiol. 2005;33(4):2407. doi: 10.1111/j.1600-0528.2005.00231.x.

34. El-Hawary YM, El-Sayed B, Abd-Alhakem G, Ibrahim FM. Deciduous teeth structure changes in congenital heart disease: ultrastructure and microanalysis. Interventional Medicine \& Applied Science. 2014;6(3):111-7. doi: 10.1556/IMAS.6.2014.3.3. 